\title{
The Impoliteness Strategies of Netizens' Comments on Trump and Jokowi's Tweets about Covid-19
}

\author{
Dhiant Asri ${ }^{1,2 *}$, Adrianis Adrianis ${ }^{1}$, and Ike Revita ${ }^{1}$ \\ ${ }^{1}$ Afiliation: English Department, FIB Universitas Andalas, Padang, Sumatera Barat, Indonesia \\ ${ }^{2}$ English Department, FIB Universitas Andalas, Padang, Sumatera Barat, Indonesia \\ *Corresponding author. Email: dhiantasri@hum.unand.ac.id
}

\begin{abstract}
The sophistication of technology makes all information in one click away. The easiness in sharing and exchanging any news creates a virtual world community with active netizens just like in the real world. Netizens communicate actively through sending the latest statuses and other netizens give any comments later. The various comments provoke further comments. Twitter is one of the social media that is widely used by various groups with some purposes, one of them is for giving information and education. Netizens' tweets have the important role in spreading the news globally. It can be seen from the existence of accounts of the Head of State and other related official accounts. The news of the Corona Virus towards the end of 2019 receives breathless attention from netizens. In a short amount of time, the news of Corona Virus pandemic becomes the trend topic on various social media. In this case, American and Indonesian netizens wait eagerly about Trump and Jokowi's tweets about COVID-19, with various comments that follow. This description formulates the problem in this study. It elaborates the impoliteness strategies of netizens' comments on Trump and Jokowi's tweets about COVID-19. Then, the result of this study is to enrich politeness and impoliteness study in Pragmatic Class.
\end{abstract}

Keywords: The Impoliteness Strategies, Pragmatics, Covid-19, Jokowi, and Trump

\section{INTRODUCTION}

Social media has a big role in spreading information globally. This is inseparable from the active role of netizens in updating their status and comments in social media. Social media has shortened the distance and time to exchange news and break the boundaries in communication. Twitter is a social media application that is used by the huge netizens. Twitter's features can be used easily in conveying any expressions.

The widespread infection of the Corona Virus since the end of 2019 and becoming a pandemic in the next two months, can be tracked from netizens' tweets on Twitter. The official accounts becomes a reference for netizens to follow the news of the Corona Virus spreading. Twitter accounts provide a variety of information, education, and socialitation about some ways to fight the virus. Netizens respond with various comments and then provoke any other responses. Donald J. Trump and Joko Widodo's tweets about COVID-19 get a huge attentiveness from American and Indonesian netizens.

In general, the impoliteness has been discussed widely from many different points of view. In particular, the analysis of the impoliteness strategies of netizens' comments on Trump and Jokowi's tweets about COVID-19 has ever studied before. Related to this study, there are three previous studies of the impoliteness can be references.

First, the study on the netizens' sarcasm in the comments of Lambe Turah's Instagram which was conducted by Elen Inderasari et al [3]. The result of this study has been published in the Semantic Journal vol. 8, no. 1, February 2019. This Study examined the violations of politeness in the comments of Lambe Turah's Instagram. The violation was due to the use of sarcasm to others. Furthermore, several factors caused the impoliteness were also found, namely the speaker's desire to show their selfexistence, showing the expressions, doing virtual communication and having free in social media.

Second, there was a study on hate speech in social media by Dian Junita Ninggrum et al [4]. The result of this study has been published in scientific journal The Korpus Vol. II, No. III, on December 2018. This research examined hate speech as the language phenomenon which opposed to the politeness. This aims of this study were to describe the forms of hate speech in social media and the types of illocutionary acts in netizens' comments on Facebook. The 
results of this study indicated the forms of hate speech included forms of insult, incitement, political provocation, defamation, blasphemy, and spreading fake news (hoax). They were classified into four topics, namely political, social, economic and religious issues. The types of illocutionary speech acts included $32.63 \%$ assertive, $20.63 \%$ directive, $9.26 \%$ commissive, $35.9 \%$ expressive, and $1.58 \%$ declarative with 882 data from 20 contexts.

Third, the study on the impolite comments on Instagram: a politicopragmatic study. This research was conducted by Hari Kusmanto et al [5]. The results of this study have been published in journal The Kata Vol. 3, No. 2 on October 2019. The aim of this study was to describe the forms of the impolite comments on Instagram of the followers of the Liputan6. In collecting the data, this study used the documentation method and note-taking techniques. The data analysis in this study used the extralingual matching method. The result of this study showed that many followers of the Instagram of Liputan6 used comments that contained critics, insults, and discredit to the hearer and giving few compliments

Dari uraian penelitian yang telah dilakukan maka dapat disimpulkan bahwa belum ada penelitian khusus tentang analisis ketidaksantunan komentar netizen pada kicauan COVID-19 Donald J. Trump dan Joko Widodo. Kajian ini akan diteliti dengan mengunakan sudut pandang yang berbeda.

From the description of the research that has been done, it can be concluded that there has been no specific research on the analysis of the impoliteness of netizen comments on the tweets of COVID-19 by Donald J. Trump and Joko Widodo. This study will be examined using a different point of view.

Donald J. Trump (Trump) is the President of the United States who will end his term of service at the end of 2020. The United States is the superpower country. It has the tremendous impact to other countries in the world. Trump in his political campaign, conducts any references for immigrant laws. Meanwhile, Joko Widodo (Jokowi) is the President of Indonesia who was re-elected in 2019. Indonesia is as the largest country in Southeast Asia has an important role in the distribution of population in the Asian region. In his second period, Jokowi actives in developing bilateral and multilateral relations with various countries. China is one of them. The current news of the spreading of the Corona Virus pandemic on both of their Twitter accounts are followed by their enthusiastic followers. The large number of netizens' comments show their great excitement and interest. The example of the impoliteness in netizens' comments on Donald J. Trump and Joko Widodo's tweets about COVID-19, can be seen in the following snippets:

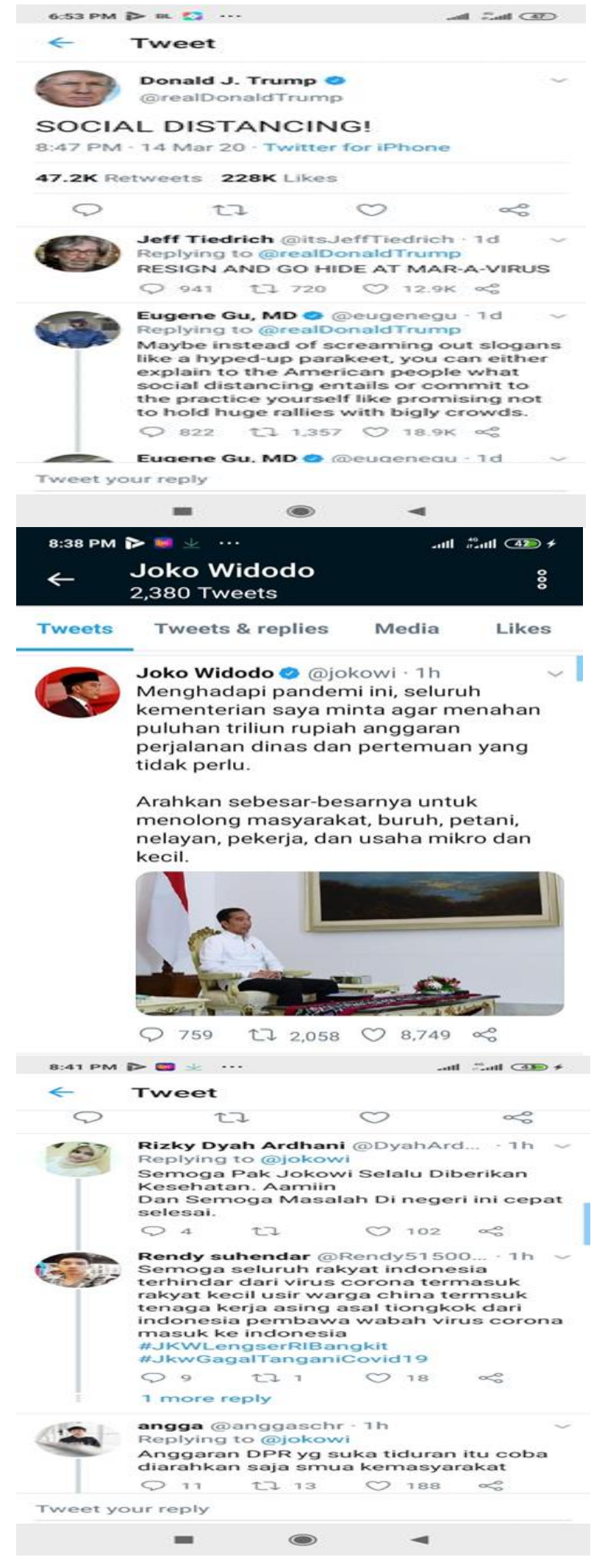


The elucidation above shows netizens' comments on Donald J. Trump and Joko Widodo's tweets about COVID19. It indicates the use of impoliteness in both accounts. Therefore, the purpose of this study is to elaborate the identification of the impoliteness strategies of netizens' comments on Donald J. Trump and Joko Widodo's tweets about COVID-19. Theoretically, the aim of this study is to apply pragmatic competence in analyzing language phenomenon in factual and viral news. Practically, this study is to corroborate the enrichment of politeness and impoliteness study in Pragmatic Class.

\section{METHODS}

This study is the descriptive comparative study in the qualitative approach. In collecting data, this study use the documentary method. The documentary method is the collection of data from written materials and other relevant materials, such as books, civil records, personal documents, visual documents and popular culture, and artifacts [6]. The data for this study are taken from the impoliteness in netizens' comments on Donald J. Trump and Joko Widodo's tweets about COVID-19. Their tweets are taken from the three tweets about COVID-19 which have the most netizens' comments every month from January 2020 to June 2020. The data reflect the use of impoliteness strategies.

Impoliteness is an extension of politeness research. Culpeper formulates impoliteness as communicative behavior that is intended intentionally to make people really loses face, or at least people feels loses face [7]. Contrary to politeness, impoliteness does not protect the face of the hearer or the speaker himself. The data are analyzed by using Culpeper's theory. Culpaper explains in five impoliteness strategies [1], namely: (1) bald on record impoliteness, facethreatening act performs in clear, unambiguous, and direct point; (2) positives impoliteness, this strategy aims to damage the addressee's positive face wants; (3) negative impoliteness, this strategy aims to damage the addressee's negative face wants; (4) mock politeness, this strategy performed face threatening acts using politeness strategy that obviously insincere, or in other word this strategy is used politeness for impoliteness. It happened when the speaker says something in some word but they do not mean that, the meaning of the word is the opposite meaning; and (5) withhold politeness, the absence of politeness strategy is works, There is no politeness work in this strategy. As in the context, this strategy can not be found.

In interpreting the use of impoliteness strategies in the data, this study considers related context. Context relates to the language situation (speech event). Context has a strong impact in interpreting the meaning of words. Context is something that accompanies or is with the text and becomes the environment or situation of language use. Context concerns to linguistic interactions in speech or more that involve some components. They are speakers and hearers with one main utterance in a certain time, place and situation [2].

\section{RESULTS AND DISCUSSION}

This study discusses the impoliteness strategies of netizens' comments on Donald J. Trump and Joko Widodo's tweets about COVID-19. The tweets of the two Heads of State about Covid-19 receive great attention from their huge followers. Thus, netizens give various comments to their tweets. The netizens' comments showed their pros and cons toward the tweets.

The netizens of the two Heads of State also have a different tendency in using the strategy of impoliteness. From all off the netizens' comments, only four impoliteness strategies can be found. The withhold politeness strategy can not be found in the netizens' comments. This impoliteness strategy can not occur because the context for this strategy is not fulfilled.

The Bald on Record strategy is more widely used by netizens in commenting Trump's tweets and less used by netizens in commenting Jokowi's tweets. This impoliteness strategy can be found in some examples of netizens' comments on Trump's tweet, such as:

\section{a.Trump lies! @Kenyazion}

b.Add China to the travel ban. @Cernovich

c.because they were stupid enough to believe trump. @Tango_Juliette

d.We trust the @CDCgov But, we don't trust Trump. @TomShafShafer

\section{e.YOU HAVE FAILED AMERICA!!!! RESIGN!!!!!!} @ JodieHMoss

The Bald on Record strategy on netizens' comments like the one above can also be found in Jokowi's tweets with the smaller number, such as:

a.Corona pak bukan korona!

b.Plin-plan amat pak!

c.Sampean kalah serius sama anies pak. Anies udah concern bapak masi tola tole kanan kiri.

The netizens' comments are conveyed to blame and criticize Trump and Jokowi directly and repeatedly. Their impoliteness strategy causes a great loss to the image of the two Heads of State. They directly criticize Trump and Jokowi's plans, performances, reactions, and policies. In considering some related factors, all of their efforts are never enough to make happy their followers.

Positive impoliteness is an impoliteness strategy that is deliberately carried out to threaten the positive face of the hearer. Actions in threatening positive faces include disapproval, criticism, acts of humiliation or embarrassment, complaints, anger, accusations, insults, conflicts, challenges, and so on. Comments from netizens can be found on the status of the two Heads of State. They are: 
1.Trump:

a.The best contain method is to isolate anyone and anything from China for now! We don't need them! @VN_USA4Trump

The netizens comment on Trump's tweet at 27/01/20, 9.56 PM "We are in very close communication with China concerning the virus. Very few cases reported in USA, but strongly on watch. We have offered China and President $\mathrm{Xi}$ any help that is necessary. Our experts are extraordinary!"

In this comment, netizen shows disaproval to Trump's tweet. Netizen wants to issolate and reject China and all things relates to China. This rejection is becaused Corona Virus is found in China firtsly. Then, it spreads to other countries in the world.

b.I got an idea donnie Why don't you go over to China to check out the virus first hand. @ KCorcor2770

The netizens comment on Trump's tweet at $30 / 01 / 20,7.06$ AM "Just received a briefing on the Coronavirus in China from all of our GREAT agencies, who are also working closely with China. We will continue to monitor the ongoing developments. We have the best experts anywhere in the world, and they are on top of it $24 / 7$ !"

In this comment, netizen complains to Trump's tweet. Netizen also calls Donnie to Trump. This call is not deserved to an American President. Netizen also inderectly accuses that the information from China can not be accepted without having the real evidence.

c.No, it is not under control.

Decades of unintelligent policies by the Republican party, combined with your utter incompetence and corruption, has brought our great nation to its knees. It's an abomination.@MtnMD K. Sennholz MD

The netizens comment on Trump's tweet at 25/02/20, 4.42 AM "The Coronavirus is very much under control in the USA. We are in contact with everyone and all relevant countries. CDC \& World Health have been working hard and very smart. Stock Market starting to look very good to me!"

In this comment, netizen states the fakes in Trump's tweet. Netizen insults by saying abomination for the fakes. This shows that netizen is anger to all of the disordered condition.

d.Don't trust the Communist Chinese Party. @ RealMarkKennedy

The netizens comment on Trump's tweet at 27/03/20, 12.19 PM "Just finished a very good conversation with President Xi of China. Discussed in great detail the CoronaVirus that is ravaging large parts of our Planet. China has been through much \& has developed a strong understanding of the Virus. We are working closely together. Much respect!"
In this comment, netizen rejects to trust Communist Chinese Party. Netizen's rejection is caused by Trump's tweets. Trump in his tweet, praises the chinese efforts in fighting Corona Virus. Netizen can not trust it because the facts do not prove it.

e.The entire planet is laughing at you, Spanky. YOU ARE A JOKE.BLEACH YOURSELF. @ mmpadellan

The netizens comment on Trump's tweet at 26/04/20, 3.30 AM "Was just informed that the Fake News from the Thursday White House Press Conference had me speaking \& asking questions of Dr. Deborah Birx. Wrong, I was speaking to our Laboratory expert, not Deborah, about sunlight etc. \& the CoronaVirus."

In this comment, netizen calls spanky to Trump. This call is not appropriate for a President. Netizen calls him spanky because Trums show his contradiction to Dr. Brix in his tweet. Netizen thinks this contradiction is Trump's foolishness since Dr. Brix specializes in immunology and vaccine research and has served as Corona Virus Response Coordinator for the White House Corona Virus Task Force since February 2020.

\section{Jokowi:}

a.KacungTetapKacungPlongaPlongoPENDUSTA

@ rha_tjoensimatu

The netizens comment on Jokowi's tweet at 13/03/2020, 9:58 PM "Pengawasan ketat di Bandara Seokarno-Hatta dilakukan dengan memberlakukan dua pintu masuk berbeda bagi negara-negara yang diwaspadai. Penumpang dari Tiongkok, Italia, Korea Selatan, dan Iran, akan diperiksa sampai tiga kali. Di luar negara itu, diperiksa dua kali."

In this comment, netizen wants to criticise Jokowi's tweet. Netizen says about the lackey who will always be lackey with dullness and fib. Netizen thinks that the procedures in International arrival gates are not smart solutions in monitoring and fighting Corona Virus.

\section{b.Ini Jokowi kosple kan. @ riizkyprdna}

The netizens comment on Jokowi's tweet at 02/04/2020, 5:39 PM "Ramadan tahun ini kita akan lalui saat kita berusaha mencegah meluasnya penyebaran Covid19. Persiapannya harus sejak dini, terutama soal ketersediaan bahan pokok dan pangan di tengah masyarakat. Sejauh ini, pasokan beras, daging, telur, gula, terigu, dll masih baik."

In this comment, netizen says kosple to Jokowi. This call is not suitable for a Head of State. Netizen says this because Jokowi's tweet is assumed as fake.

c.Maksudnya Berdamai dgn para BIBIT COVID-19 TKA CHINA. @ Muslim

The netizens comment on Jokowi's tweet at 07/05/2020, 5:50 PM "Sampai ditemukannya vaksin yang efektif, kita harus hidup berdamai dengan Covid-19 untuk beberapa waktu ke depan. Sejak awal pemerintah memilih 
kebijakan Pembatasan Sosial Berskala Besar, bukan lockdown. Dengan PSBB, masyarakat masih bisa beraktivitas, tetapi dibatasi."

In this comment, netizen mention China is as seeds of Corona Virus since the first case was found there. This disapproval is caused Jokowi asks to live peacefully with Corona Virus in his tweet. The fact of the number of the confirmed cases and deaths everyday, provokes netizen to state this comment.

d.Saya tunggu penjelasan pak Luhut aja pakde. @agrpaqm

The netizens comment on Jokowi's tweet at 06/04/2020, 1:16 PM "Untuk memutus rantai penyebaran Covid-19 di lembaga pemasyarakatan, pemerintah setuju untuk memberikan pembebasan bersyarat kepada sejumlah narapidana tindak pidana umum. Pembebasan secara bersyarat ini tidak berlaku untuk koruptor. Bahkan dibicarakan di rapat pun tidak pernah."

In this comment, netizen ignores Jokowi's explanation. Netizen announces indirectly that Luhut's explanation is trustworthiest. Jokowi's tweets is considered not explainable for that information.

e.Ya dibikin aturan melarangnya dong ganteng. @ nebuzekhar

The netizens comment on Jokowi's tweet at 18/04/2020, 2:24 PM “Tak mudik bukan karena tak rindu. Tapi karena sayang pada ayah dan ibu."

In this comment, netizen replies Jokowi's tweet with flirty style. This tweet prohibits peoples to return to hometown. The flirty style is not suitable in replying a President's tweet, even though in the social media.

Negative impoliteness is an impoliteness strategy to attack the negative face of the hearer that it is not hindered. Actions of threatening negative faces include commands, requests, suggestions, advice, warnings, threats, challenges, offers, promises, praise, and expressions of negative feelings such as hatred and anger.

\section{Trump:}

a.Don't trust China for any information on this. Whatever numbers they give you, multiply it by 10 . Maybe 100 . @JDRucker

The netizens comment on Trump's tweet at 30/01/20, 7.06 AM "Just received a briefing on the Corona virus in China from all of our GREAT agencies, who are also working closely with China. We will continue to monitor the ongoing developments. We have the best experts anywhere in the world, and they are on top of it 24/7!"

In this comment, netizen conveys disagreement to Trump's idea in believing any information from China. There is a speculation that china reduces the numbers of the confirmed cases and the deaths in the report. Therefore, netizen suggests Trump to recheck the data from China. b.The only thing you've wanted to protect Don is the stock market. You've dismantled government agencies and cut funding to protect us from a pandemic. You've muzzled the CDC so we can't hear the truth. You've put an inept science denier in charge. \#virus @ZPoet

The netizens comment on Trump's tweet at 28/02/20, 12.43 PM "The Do Nothing Democrats were busy wasting time on the Immigration Hoax, \& anything else they could do to make the Republican Party look bad, while I was busy calling early BORDER \& FLIGHT closings, putting us way ahead in our battle with Coronavirus. Dems called it VERY wrong!"

In this comment, netizen proposes Trump to protect the stock market. In this case, netizen also criticizes Trump's acts and policies in fighting Corona Virus. Netizen assumes that Trump does not consider to his peoples.

c.You delayed the response to the coronavirus by weeks to try to protect the Stock Market and your re-election. You gave our stockpile to China and then lied about it. You belong in prison. @DebbieSVA

The netizens comment on Trump's tweet at 30/03/20, 6.17 PM "Nancy Pelosi and the Democrats delayed the Workers Help/Stimulus Bill by over a week, trying to add real "junk" into the Bill. Got some bad things, having nothing to do with those affected by the Virus, included. Republicans need their votes until we WIN BACK THE HOUSE IN 2020!"

In this comment, netizen expresses the anger because Trump lies to his peoples. His statement is paradox. Therefore, netizen proposes him to be responsible for all his mistakes.

d.I feel we need to put more pressure on $\mathrm{Xi}$, we know it was a bio-weapon and they haven't apologized for anything. The Chinese people who have died deserve justice, many of them aren't counted in the official numbers. So many of them. @Ben_Chasteen

The netizens comment on tweet 27/03/20,12.19 PM "Just finished a very good conversation with President Xi of China. Discussed in great detail the CoronaVirus that is ravaging large parts of our Planet. China has been through much \& has developed a strong understanding of the Virus. We are working closely together. Much respect!"

In this comment, netizen suggests Trump to be more firm to Xi. Trump is supposed to be lenient to China. Netizen wants $\mathrm{Xi}$ to be honest in reporting all of the causes of Corona Virus in China. Netizen wants the transparent news from China. In order to respect the pandemic victims, China must confirm and release the real number of deaths by Corona Virus.

e.The only thing trump is concerned with is how he looks on the world stage. That $\&$ how much money he can steal from hard working American citizens. He's only saying this now because he doesn't want to lose votes in November. Too late. Trump's had 3 yrs to do something. Time's up. @ 100TrueBlue 
The netizens comment on Trump's tweet at 12/03/20, 5.04 AM "The Media should view this as a time of unity and strength. We have a common enemy, actually, an enemy of the World, the CoronaVirus. We must beat it as quickly and safely as possible. There is nothing more important to me than the life \& safety of the United States!"

In this comment, netizen claims that Trump's time is over. Trump is judged just waste time, just busy with himself, and waste people's money for nothing. In this case, netizen assumes that Trump does not fight Corona Virus fervently.

\section{Jokowi:}

a.Janji apalagi ini pakde...??? Janjimu yg dulu2 juga blm terlaksana. Sampaikapan mengobral janji????? @lanus_awake

The netizens comment on Jokowi's tweet at 17/02/2020, 5:51 PM "Saat daya saing pariwisata Indonesia meningkat dari tahun ke tahun, wabah virus korona terjadi di Tiongkok. Salah satu yang sedang kita pertimbangkan untuk mengantisipasi dampak wabah ini ke pariwisata kita adalah pemberian insentif untuk wisatawan, termasuk travel bironya."

In this comment, netizen proposes Jokowi to fulfills his promises before coming to the next promises. Jokowi's tweet provokes netizen to be angry because netizen is disappointed. Netizen assumes Jokowi's consideration for tourism is not the most important action in fighting Corona Virus. Therefore, netizen reminds Jokowi to fulfill his promises before.

b.Pak Jokowi gimana dgn uang Rp $72 \mathrm{M}$ buat influencer utk corona? Hubungannya influencer dgn corona apa? Bukankah yg tepat itu uang untuk pencegahan dan penanganan corona? Harus jelas lho tujuan dan cara utk meraih tujuan itu? @fadhlierlanda

The netizens comment on Jokowi's tweet at 25/02/2020, 8:50 PM "Wabah virus korona tentu berdampak bagi perekonomian global, termasuk Indonesia. Untuk mengantisipasinya, saya minta kementerian dan lembaga untuk lebih cepat membelanjakan anggaran, mencairkan dana desa, juga program bantuan sosial untuk menggenjot perekonomian dalam negeri."

In this comment, netizen warns Jokowi to use and manage financial policy as well as possible. Jokowi is assumed to use it incorrectly since Jokowi proposes financial support for the influencers. Netizen wants legibility and clearness in Jokowi's financial policy.

c.Pak i think we need lockdown for a while :') @ jannahismii The netizens comment on Jokowi's tweet at 13/03/2020, 9:58 PM "Pengawasan ketat di Bandara Seokarno-Hatta dilakukan dengan memberlakukan dua pintu masuk berbeda bagi negara-negara yang diwaspadai. Penumpang dari Tiongkok, Italia, Korea Selatan, dan Iran, akan diperiksa sampai tiga kali. Di luar negara itu, diperiksa dua kali."
In this comment, netizen suggests lockdown to Jokowi. This sugestion is becaused Jokowi still open the gates of international arrival. Netizen assumes that Jokowi does not consider the wave of Corona Virus in Indonesia and other countries.

d.Anggaran DPR yg suka tiduran itu coba diarahkan saja semua kemasyarakat. @anggaschr

The netizens comment on Jokowi's tweet at 16/03/2020, 6:46 PM "Menghadapi pandemi ini, seluruh kementerian saya minta agar menahan puluhan triliun rupiah anggaran perjalanan dinas dan pertemuan yang tidak perlu. Arahkan sebesar-besarnya untuk menolong masyarakat, buruh, petani, nelayan, pekerja, dan usaha mikro dan kecil."

In this comment, netizen criticizes senators who like to sleep but are paid by the people's money. Due to Jokowi's tweet, netizen hopes the people's money can be reallocated to peoples.

e.Sebaiknya anda ganti menteri menteri yang tidak bisa kerja maksimal di tengah krisis wabah covid dan krisis ekonomi. Buktikan kalau anda bertanggung jawab terhadap 267 juta jiwa masyarakat Indonesia. Tegas nya kapan..?? @ HukumDan

The netizens comment on Jokowi's tweet at 28/06/2020, 7:09 PM “Tiga bulan ini kita dalam suasana pandemi, suasana krisis. Maka, saya mendorong para menteri dan pimpinan lembaga, untuk bekerja ekstra keras. Segala tindakan dan keputusan harus luar biasa. Semua demi tanggung jawab kepada 267 juta rakyat Indonesia."

In this comment, netizen asks Jokowi's responsibility for his peoples. In Jokowi's tweet, Jokowi states to push all of his ministers and staff in fighting Corona Virus. Netizen judges that the performance of Jokowi's ministers and staff are not maximal yet. Indonesia is in financial crisis. Therefore, netizen asks Jokowi to replace them soon.

Mock politeness is an impoliteness strategy that uses pseudo or fake politeness. This strategy is also called as sarcasm.

1.Trump:

a.Glad you're not banning US citizens with the virus from returning home, like you suggested for those with Ebola.

The netizens comment on Trump's tweet at 25/01/20, 4.18 AM "China has been working very hard to contain the Coronavirus. The United States greatly appreciates their efforts and transparency. It will all work out well. In particular, on behalf of the American People, I want to thank President Xi!'

In this comment, netizen satirizes Trump's tweet Netizen shows disagreement because Trump appreciates Xi greatly. In this case, netizen seems to be grateful for Trump's effort in fighting Corona Virus. In fact, netizen judges that Trump do nothing in fighting Corona Virus. 
b.Thank you President Trump for keeping your promise to build the Wall!!! Best POTUS EVER!!! @elianatrue

The netizens comment on Trump's tweet at 26/02/20, 9.29 AM "CDC and my Administration are doing a GREAT job of handling Coronavirus, including the very early closing of our borders to certain areas of the world. It was opposed by the Dems, "too soon", but turned out to be the correct decision. No matter how well we do, however, the....."

In this comment, netizen quips Trump's Wall. In his 2016 presidential campaign, the border wall is a hot issue from Trump for immigrant. In fact, in this pandemic attack, the wall is useless. It can not protect people from the pandemic wave.

c.Trump blatantly lying to the American peoples' faces. But Tony Posnanski and Bishop Swan are spitting truth bombs as usual. I thank these two brave men for holding our soulless leader accountable every day! @LongIsland_Tony

The netizens comment on Trump's tweet at 12/05/20, 6.56 PM "Remember this, every Governor who has sky high approval on their handling of the Coronavirus, and I am happy for them all, could in no way have gotten those numbers, or had that success, without me and the Federal Governments help. From Ventilators to Testing, we made it happen!"

In this comment, netizen seems to say thanks to Posnanski and Swan. It is the netizen's sarcasm for both of them. Netizen evaluates their leader is soulless and is surrounded by men like them.

d.It will forever be known as the trump virus. \#trumpvirus.@GeorgeT2011

The netizens comment on Trump's tweet at 26/05/20, 3.16 AM "Great reviews on our handling of Covid 19 , sometimes referred to as the China Virus. Ventilators, Testing, Medical Supply Distribution, we made a lot of Governors look very good - And got no credit for so doing. Most importantly, we helped a lot of great people!"

In this comment, netizen expresses the disappointment in naming Trump's name to the virus. Giving Trump's big name to the virus is a sarcasm for Trump because the virus has already named before.

e.I voted for you. I backed you. I defended you $\mathrm{Mr}$ President. I was wrong. @Kj11Karrn

The netizens comment on Trump's tweet at 26/06/20, 10.54 AM "Coronavirus deaths are way down. Mortality rate is one of the lowest in the World. Our Economy is roaring back and will NOT be shut down. "Embers" or flare ups will be put out, as necessary!"

In this comment, netizen wants to show the remorse, even though netizen states Trump is devoted before. Trump's statement is assumed as fake. Netizen counts that it is inconsistent with fact.
2.Jokowi:

a.Alhamdulillah, Pak lapor..harga gula melambung @faisal_haq75

The netizens comment on Jokowi's tweet at 25/02/2020, 8:50 PM "Wabah virus korona tentu berdampak bagi perekonomian global, termasuk Indonesia. Untuk mengantisipasinya, saya minta kementerian dan lembaga untuk lebih cepat membelanjakan anggaran, mencairkan dana desa, juga program bantuan sosial untuk menggenjot perekonomian dalam negeri."

In this comment, netizen gives sarcasm to Jokowi. This sarkasm is provoked by Jokowi's tweet. The tweet explains some economic policies are proposed. In fact, netiizen sees the price can not be controlled.

b.Tenang pak, semua aman. Para Buzzer yang bapak gaji 27 miliyar siap memoles bapak. @ PenyairRadikal

The netizens comment on Jokowi's tweet at 25/02/2020, 8:50 PM "Wabah virus korona tentu berdampak bagi perekonomian global, termasuk Indonesia. Untuk mengantisipasinya, saya minta kementerian dan lembaga untuk lebih cepat membelanjakan anggaran, mencairkan dana desa, juga program bantuan sosial untuk menggenjot perekonomian dalam negeri."

In this comment, netizen satirizes Jokowi's tweet. Netizen assumes that Jokowi does not need to do more. Jokowi's influencers are ready to cover all things.

c.Keren betul.. saat negara lain udah melakukan larangan kunjungan dari negara" yang paling banyak mengalami kasus corona, negara kita masih menerima.. kesehatan masyarakat emang ga dipeduliin sama bapak ini.. beliau hanya peduli tentang stabilitas ekonomi. @awas_io

The netizens comment on Jokowi's tweet at 13/03/2020, 9:58 PM "Pengawasan ketat di Bandara Seokarno-Hatta dilakukan dengan memberlakukan dua pintu masuk berbeda bagi negara-negara yang diwaspadai. Penumpang dari Tiongkok, Italia, Korea Selatan, dan Iran, akan diperiksa sampai tiga kali. Di luar negara itu, diperiksa dua kali."

In this comment, netizen seems to compliment Jokowi at the beginning. Then, netizen judges Jokowi does not pay attention to his peoples and only cares to economic stabilities. This comment is provoked by Jokowi's tweet about the procedures at International arrival gates.

d.Mantep pakde . Yang miliaran buat buzzer juga ya pak. @ AdhiePerwira

The netizens comment on Jokowi's tweet at 16/03/2020, 6:46 PM "Menghadapi pandemi ini, seluruh kementerian saya minta agar menahan puluhan triliun rupiah anggaran perjalanan dinas dan pertemuan yang tidak perlu. Arahkan sebesar-besarnya untuk menolong masyarakat, buruh, petani, nelayan, pekerja, dan usaha mikro dan kecil."

In this comment, netizen still hints Jokowi's influencers. Netizen assumes that people's money should not allocated for them. Jokowi must return it back to people. 
e.Aku Rindu dengan PDIP mu yang dulu pak.. Partai nya wong licik,eh wong cilik maksudnya. Apr 18

The netizens comment on Jokowi's tweet at 18/04/2020, 2:24 PM "Tak mudik bukan karena tak rindu. Tapi karena sayang pada ayah dan ibu."

In this comment, netizen quips Jokowi's tweet. It is about Jokowi's appeal to stay at home. Netizen reminds Jokowi about the aim of PDIP at first time for common people

\section{CONCLUSION}

The conclusion in this study shows that netizens' comments on Trump and Jokowi's tweets use four impoliteness strategies. The tweets of facts and policies on the status of the two Heads of State provoke various comments from netizens. The smart netizens filter and share information on social media. It is the key to communicate properly and correctly in creating unity and integrity. Netizens must work hand in hand to fight and break the chain of COVID-19.

\section{ACKNOWLEDGMENT}

This work was supported by English Department and FIB Universitas Andalas, Padang, Sumatera Barat, Indonesia.

\section{REFERENCES}

[1] Jonathan Culpeper, Toward an Anatomy of Impoliteness, Journal of Pragmatics 25(3) (1996) 349-367. DOI: http://doi.org/ 10.1016/03782166(95)00014-3

[2] J. J. Gumperz and D. Hymes, Direction in Sociolinguistics: the Ethnography of Communication. New York: Holt, Rinehart and Winston Inc., 1972.

[3] E. Inderasari1, F. Achsani and B. Lestari. Bahasa Sarkasme Netizen dalam Komentar Akun Instragram Lambe Turah, J. Semantik 8(1) 201937 49. URL: $\underline{\text { http://e- }}$ journal.stkipsiliwangi.ac.id/index.php/semantik/art icle/view/1232/0

[4] D. J. Ningrum, Suryadi, dan Dian Eka Chandra Wardhana, Kajian Ujaran Kebencian di Media Sosial, J. Ilmiah Korpus 2(3) (2018) 241-252. DOI: http://doi.org/10.33369/jik.v2i3.6779

[5] Hari Kusmanto and Christina Purbawati, Ketidaksopanan Berkomentar pada Media Sosial Instagram: Studi Politikopragmatik. J. Kata. 3(2) (2019) 217-227. DOI: http://doi.org/10.22216/jk.v3i2.4338

[6] S. B. Merriam, Qualitative Research: a Guide to Design and Implementation. San Francisco: JosseyBass, 2009.
[7] K. Rahardi, Pragmatik: Fenomena Ketidaksantunan Berbahasa. Jakarta: Penerbit Erlangga, 2016. 